\title{
PENGARUH TERAPI REMINISCENCE INDIVIDU TERHADAP SKOR DEPRESI LANSIA
}

\author{
Erlina Hermawati \\ Erlina Hermawati: Dosen Keperawatan STIKES Duta Gama Klaten, J1. Solo-Jogja \\ Km 5 Ngaran, Mlese, Ceper, Klaten- 57465, E-mail : arsyfakirana5@gmail.com
}

\begin{abstract}
Abstrak
Latar belakang: Jumlah lansia di dunia semakin meningkat seiring bertambahnya waktu. Lansia telah mengalami banyak perubahan baik secara fisik maupun mental. Berbagai masalah kesehatan psikososial yang sering terjadi pada lansia adalah depresi. Salah satu psikoterapi yang bisa digunakan untuk mengatasi depresi adalah dengan terapi reminiscence. Terapi reminiscence merupakan terapi mengenang masa lalu yang menyenangkan pada masa anak-anak, remaja, dewasa, berkeluarga dan evaluasi integritas diri. Tujuan: Untuk menganalisis pengaruh terapi reminiscence individu terhadap skor depresi lansia. Metode: Penelitian ini merupakan penelitian pre eksperimen dengan desain one group pre test post test. Teknik pengambilan sampel secara purposive sampling dengan menggunakan kriteria inklusi dan eksklusi. Jumlah responden 10. Terapi reminiscence individu dilaksanakan sebanyak 5 sesi masing-masing sesi 60 menit. Tingkat depresi diukur dengan menggunakan GDS (Geriatric Depression Scale). Hasil Uji normalitas p value > 0,05 yang menunjukkkan data berdistribusi normal. Analisa bivariat dengan menggunakan Paired Sample T Test. Hasil: Rata-rata skor depresi pre test 7,70, dan rata-rata skor depresi post test adalah 4. Terdapat perbedaan skor depresi pre test dan post test dengan nilai $p$ value $0,00<0,05$. Kesimpulan: Terdapat pengaruh terapi reminiscence individu terhadap skor depresi lansia dengan mean changes 3,70, sehingga terapi reminiscence bisa direkomendasikan sebagai salah satu pskioterapi dalam menurunkan skor depresi pada lansia di komunitas. Rekomendasi : Penelitian ini bisa diimplikasikan kepada perawat jiwa komunitas untuk mengintegrasikan terapi reminiscence ke dalam pelayanan asuhan keperawatan pada lansia sebagai salah satu upaya mennagani masalah depresi pada lansia.
\end{abstract}

Kata kunci: skor depresi lansia, terapi reminiscence individu

\begin{abstract}
Background: The number of elderly in the world was increased over time. The elderly have experienced many changes both physically and mentally. Various psychosocial health problems that often occur in the elderly are depression. One of the psychotherapy that can be used to treat depression was reminiscence therapy. Reminiscence therapy is a therapy to reminisce about the pleasant past in childhood, adolescence, adulthood, family and self-integrity evaluation. Objective: To analyze the effect of individual reminiscence therapy on depression scores in the elderly. Methods: This research was a pre-experimental research with one group pre-test post-test design. The sampling technique was purposive sampling used inclusion and exclusion criteria. Total of respondents are 10 respondent. Reminiscence therapy was carried out in 5 sessions, each 60 minute session. The depression level was measured used the GDS (Geriatric Depression Scale). The results of normality test was $p$ value $>0.05$ which shows the data is normally distributed. Bivariate analysis used Paired Sample T Test. change of 3.70, so reminiscence therapy can be recommended as a psychotherapy in reducing depression scores in the elderly in the community. Results: The average of pre-test depression score was 7.70, and the average of post-test depression score was 4. There was a difference in pre-test and post-test depression scores with a p value of $0.00<0.05$. Conclusion: There was an effect of individual reminiscence therapy on depression scores in the elderly with a mean. Recommendation: This research can be implicated for community mental nurses to integrate reminiscence therapy into nursing care services for the elderly as an effort to deal with depression problems in the elderly.
\end{abstract}

Keywords: elderly depression score, individual reminiscence therapy 


\section{PENDAHULUAN}

Tahapan paling akhir dalam kehidupan manusia adalah lansia. WHO memberikan batasan pada lansia yaitu seseorang yang berusia 60 tahun atau lebih (WHO, 2015). Jumlah lansia di seluruh dunia akan meningkat dari 524 juta pada tahun 2010 menjadi 1,5 miliar pada tahun 2050 (WHO, 2011). Di Indonesia diperkirakan pada tahun 2010-2030 akan terjadi peningkatan jumlah lansia yang cukup signifikan dan pada tahun 2050 diperkirakan jumlah lansia menjadi 71,6 juta jiwa (Bappenas, 2015).

Lebih dari $26 \%$ lansia mengalami setidaknya satu gangguan mental atau gangguan neurologis (WHO, 2015). Gangguan mental pada lansia yang paling umum terjadi adalah demensia, depresi, kecemasan, dan masalah penyalahgunaan zat (WHO, 2015). Secara global, kejadian depresi pada lansia bervariasi antara 10-20\% (Arwani, dkk, 2019). Hasil review penelitian yang dilakukan Sarokhani di Iran sebanyak 26 studi dari tahun 2001 sampai dengan tahun 2015 dengan ukuran sampel 5781 telah diperoleh prevalensi depresi pada lansia adalah $49 \%$ pada wanita, $48 \%$ pada pria, $37 \%$ pada yang belum menikah, dan $45 \%$ yang menikah, sedangkan prevalensi depresi sangat parah 5\%, parah 19\%, sedang 33\%, dan depresi ringan 38\% (Sarokhani, Parvareh, Dehkordi, \& Sayehmiri, 2018). Menurut penelitian Pramesona (2018), sebanyak 181 lansia di tiga Kabupaten Yogyakarta didapatkan hasil 42,5\% mengalami depresi yang terdiri dari $31,5 \%$ pada wanita, dan $11 \%$ pada pria. Adapun faktor risiko yang ditemukan secara signifikan berpengaruh terhadap kejadian depresi pada lansia adalah jenis kelamin perempuan, tidak ada atau kurang dukungan sosial, memiliki lebih dari 3 penyakit kronis dan persepsi perawatan yang tidak memadai (Pramesona \& Taneepanichskul, 2018).

Salah satu penatalaksanaan untuk mengurangi depresi pada lansia adalah dengan psikoterapi. Psikoterapi yang bisa digunakan untuk mengurangi perilaku gelisah dan gejala depresi pada lansia dengan demensia adalah AMT (Aroma Massage Therapy), CST (Cognitive stimulation therapy) dan RT (Reminiscence Therapy) (Yang, Lee, Chao, Hsu, \& Wang, 2016). Terapi reminiscence merupakan salah satu intervensi psikologis bagi lansia dengan 
depresi yang telah banyak digunakan dan telah menunjukkan beberapa efek (Chen, Li, \& Li, 2012; Chueh \& Chang, 2014; Pinquart \& Forstmeier, 2012). Reminiscence adalah pengobatan noninvasif yang baik untuk pencegahan dan pengobatan penyakit mental pada lansia di Taiwan (Yen \& Lin, 2018). Terapi reminiscence merupakan salah satu intervensi yang efektif secara biaya dalam menurunkan depresi dikarenakan terapi ini relatif mudah untuk dilaksanakan dan prosedurnya tidak mempunyai efek samping yang membahayakan (Jones, 2003). Terapi reminiscence telah digunakan secara luas sebagai terapi non-farmakologis dan dapat dilakukan dengan kelompok atau secara individu (Woods et al., 2018).

Penelitian terapi reminiscence yang dilaksanakan secara individu adalah Wu, Chen, Yang, Gong, \& Hu (2018) yang melaksanakan terapi reminiscence secara individu selama 6 minggu dan hasil penelitian ini menunjukkan bahwa terapi reminiscence individu dapat meghilangkan depresi dan kecemasan pada lansia. Penelitian Tarugu, dkk (2019) juga melakukan terapi reminiscence secara individu yang dilaksanakan selama 6 sesi dengan hasil penelitian yang menunjukkan bahwa terapi reminiscence dapat menurunkan kecemasan, depresi dan kesepian pada lansia.

Beberapa penelitian mengenai terapi reminiscence di Indonesia sudah pernah dilakukan untuk mengatasi depresi pada lansia. Menurut penelitian Hidayati, Mustikasari, \& Eka Putri (2015) menunjukkan bahwa terapi reminiscence secara individu sangat efektif dalam menurunkan depresi pada lansia yang tinggal di Panti Sosial Tresna Wredha (PSTW) Provinsi Daerah Istimewa Yogyakarta, sedangkan penelitian Lestari (2016) menunjukkan bahwa tingkat depresi lansia wanita yang tinggal di Panti Wredha SA Jakarta mengalami penurunan setelah dilakukan terapi kelompok reminiscence. Hal ini juga didukung penelitian (Vitaliati, 2018) yang menunjukkan bahwa terapi kelompok reminiscence dapat menurunkan depresi pada lansia yang berada di UPT PSTW Bondowoso.

Berdasarkan penelitian sebelumnya, mayoritas terapi reminiscence pada lansia dilaksanakan 
di panti wredha, maka dari itu peneliti mencoba melakukan penelitian terapi reminiscence di tempat lain yaitu pada lansia yang tinggal di komunitas dan pelaksanaannya dilaksanakan di balai dusun atau di salah satu rumah warga. Alasan peneliti melakukan penelitian di komunitas adalah untuk mengetahui apakah terapi reminiscence juga akan efektif dalam menurunkan depresi lansia yang memiliki karakteristik berbeda dengan lansia yang tinggal di panti wredha. Karakteristik lansia yang tinggal di komunitas tentunya berbeda dengan lansia yang tinggal di panti wredha, sebagai contoh lansia yang tinggal di komunitas memiliki kebiasaan untuk berkumpul dengan warga, lansia yang tinggal di komunitas ada yang tinggal di rumah sendiri, tinggal bersama pasangan atau tinggal bersama anak dan cucunya atau extended family. Hal ini tentunya yang tidak terdapat pada lansia yang tinggal di panti wredha dan menjadi dasar peneliti memilih komunitas sebagai sasaran pelaksanaan terapi reminiscence pada lansia yang mengalami depresi.

\section{METODE}

Penelitian ini merupakan penelitian pre eksperimen dengan one group pretest-posttest design. Penelitian dilakukan di Dusun Gedangan, Desa Hargomulyo Gedangsari Gunungkidul pada bulan Februari 2021.

Teknik sampling dengan menggunakan purposive sampling dengan kriteria inklusi dan eksklusi. Adapun kriteria inklusi adalah lansia berusia di atas 60 tahun, mampu berkomunikasi dengan baik dan skor pengukuran GDS lebih dari 4. Kriteria eksklusi dalam penelitian ini adalah responden yang menjalani terapi medis (obat anti depresan) dan mengalami gangguan jiwa berat. Jumlah responden sebanyak 10 . Instrumen untuk mengukur skor depresi dengan menggunakan GDS (Geriatric Depression Scale). Terapi reminiscence dilaksanakan sebanyak 5 sesi setiap hari Sabtu dan Minggu masing-masing sesi 60 menit.

Pengambilan data dilakukan dengan mematuhi protokol kesehatan (memakai masker, mencuci tangan sebelum tindakan terapi dan wawancara, menjaga jarak minimal 1 
meter) dan dilakukan secara door to door.

Penelitian ini telah mendapatkan Surat Keterangan Layak Etik penelitian oleh Komite Etik Penelitian Kesehatan Universitas 'Aisyiyah Yogyakarta pada tanggal 07 Februari 2020 dengan nomor surat 1435/KEPUNISA/II/2020.

\section{HASIL}

Karakteristik responden berdasarkan usia, jenis kelamin dan pekerjaan

Tabel 1 Karakteristik responden berdasarkan usia, jenis kelamin, status dan tinggal bersama.

\begin{tabular}{|c|c|c|c|}
\hline Karakteristik & $\begin{array}{l}\text { Mea } \\
\mathrm{n} \\
\pm \mathrm{SD}\end{array}$ & $\begin{array}{l}\text { frekuen } \\
\text { si }\end{array}$ & $\begin{array}{l}\text { Presenta } \\
\text { se }(\%)\end{array}$ \\
\hline Usia & $\begin{array}{l}64,7 \\
\pm \\
5,6\end{array}$ & & \\
\hline 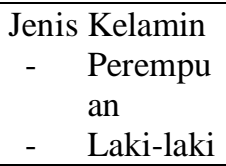 & & $\begin{array}{l}6 \\
4\end{array}$ & $\begin{array}{l}40 \\
60\end{array}$ \\
\hline \begin{tabular}{ll}
\multicolumn{2}{l}{ Status } \\
- & Menikah \\
- & Janda/Du \\
& da
\end{tabular} & & $\begin{array}{l}9 \\
1\end{array}$ & $\begin{array}{l}90 \\
10\end{array}$ \\
\hline \begin{tabular}{ll}
\multicolumn{1}{l}{ Tinggal } \\
bersama \\
$-\quad$ Sendiri \\
$-\quad$ Suami/ist \\
& ri \\
- & Anak/ \\
& Cucu
\end{tabular} & & $\begin{array}{l}1 \\
9 \\
-\end{array}$ & $\begin{array}{l}10 \\
90 \\
-\end{array}$ \\
\hline
\end{tabular}

Berdasarkan Tabel 1, dapat diketahui bahwa rata-rata usia responden adalah
64,7 tahun, mayoritas berjenis kelamin perempuan, mayoritas menikah dan mayoritas tinggal bersama pasangan suami/istrinya.

Skor Depresi sebelum dan sesudah dilakukan terapi reminiscence individu Tabel 2 Skor depresi pre test dan post test $(\mathrm{n}=10)$

\begin{tabular}{lrr} 
Skor Depresi & & \\
\cline { 2 - 3 } & Mean & SD \\
\hline pre test & 7.70 & 1.16 \\
\hline post test & 4 & 1.05 \\
\hline
\end{tabular}

Berdasarkan tabel 2 dapat diketahui rata-rata skor depresi pre test 7,70 yang menunjukkan depresi ringan dan rata-rata skor depresi post test adalah 4 yang menunjukkan tidak depresi atau normal.

Tabel 3 Hasil uji normalitas skor depresi pre test dan post test

\begin{tabular}{cccc}
\hline \multicolumn{2}{c}{ Kelompok } & $P$ value & Kesimpulan \\
\hline Skor & depresi & & \\
$(\mathrm{n}=10)$ & & 0,12 & normal \\
- & Pre test & 0,74 & normal \\
- & Post test & & \\
\hline \multicolumn{3}{c}{ Berdasarkan tabel 3 diketahui nilai $p$}
\end{tabular}
value skor depresi pre test $0,12>0,05$ dan nilai $p$ value skor depresi post test adalah 0,74>0,05 yang menunjukkan bahwa data tersebut berdistribusi normal. Karena kedua data berdisitribusi normal maka analisa data menggunakan uji Paired 
Sampel T Test untuk mengetahui apakah terdapat perbedaan skor depresi sebelum dan sesudah diberikan terapi reminiscence.

Peneliti melakukan analisis perbedaan skor depresi lansia pre test dan post test dengan menggunakan uji Paired Sampel T Test. Uji Paired Sampel T Test merupakan uji statistik parametrik yang digunakan untuk menguji perbedaan pada kelompok berpasangan dan memiliki data yang berdistribusi normal.

Tabel 4 Analisis perbedaan skor depresi pre test post test

\begin{tabular}{lrrrr}
\hline $\begin{array}{c}\text { Skor } \\
\text { depresi }\end{array}$ & F & mean & SD & P value \\
\hline Pre test & 10 & 7,70 & 1,16 & 0,00 \\
\hline Post test & 10 & 4 & 1,05 & 0,00 \\
\hline Selisih & & 3,70 & & \\
\hline
\end{tabular}

Pada tabel 4 dapat diketahui bahwa skor depresi lansia setelah diberikan terapi reminiscence mengalami penurunan secara bermakna dengan mean changes 3,70 . Nilai $p$ value $0,00<$ 0,05 , yang menunjukkan terdapat perbedaan rata-rata skor depresi sebelum dan sesudah diberikan terapi reminiscence. Rata-rata skor depresi pre test adalah 7,70 yang menunjukkan depresi ringan, dan rata-rata skor depresi post test adalah 4 yang menunjukkan tidak depresi atau normal.

\section{PEMBAHASAN}

Berdasarkan tabel 4.1 dapat diketahui bahwa rata-rata usia responden yang mengalami depresi adalah 64,7 tahun. Usia sangat berpengaruh terhadap kejadian depresi pada lansia. Lansia berusia 75 tahun ke atas cenderung mengalami depresi daripada lansia yang berusia kurang dari 75 tahun (Marta, 2012). Hal ini sama dengan penelitian Livana (2018) yang menunjukkan bahwa mayoritas lansia di Kelurahan Bandengan Kabupaten Kendal yang mengalami depresi pada usia 60 tahun hingga 74 tahun yaitu 98 (86,7\%), sedangkan yang berusia 75 hingga 90 tahun sejumlah $15(13,3 \%)$.

Jenis kelamin lansia yang mengalami depresi sebagian besar adalah perempuan. Hal ini dikarenakan perempuan lebih sering terpapar dengan stresor lingkungan dan memiliki ambang terhadap stresor lebih rendah apabila dibandingkan dengan laki-laki. Ketidakseimbangan hormon pada wanita dapat menambah tingginya prevalensi depresi pada wanita (Marta, 2012). Kaplan dan Saddock (2010) menyebutkan bahwa seseorang yang 
mengalami depresi dapat dipengaruhi oleh faktor jenis kelamin dimana hormon seks, sosialisai, cara menghadapi masalah, frekuensi dan reaksi stres, peran sosial dan budaya yang tidak sama. Hasil penelitian Livana (2018) di Kelurahan Bandengan menunjukkan bahwa perempuan lebih banyak mengalami depresi yaitu sebanyak 50\% dibandingkan laki-laki, yang hanya $36,6 \%$.

Perempuan memiliki risiko mengalami depresi lebih tinggi dikarenakan adanya perubahan hormon estrogen. Penurunan hormon estrogen dapat mempengaruhi perubahan emosi. Penurunan self esteem atau harga diri pada perempuan lebih besar dibandingkan laki-laki, sehingga akan menimbulkan kehilangan rasa percaya diri dan mengalami gangguan interpersonal. Kelebihan sekresi corticotropin-releasing hormone pada permepuan sebagai akibat dari hiperaktifnya hypothalamic-pituitaryadrenal axis (HPA-axist) dapat berdampak pada episode depresi (Monteleone, 2011). Peningkatan cortisol dapat menyebabkan ketidakseimbangan pada neurotransmitters yaitu norephineprine, serotonin, dan dopamine. Peningkatan jumlah serotonin menyebabkan penurunan kadar norepinephrine. Norepinephrine merupakan neurotransmitter yang mempunyai hubungan dengan fungsi kesiagaan tubuh, perhatian, energi, motivasi, penghargaan, kesenangan, dan beberapa hal yang menarik dalam hidup (Nutt, 2008).

Status perceraian pada seseorang akan berisiko lebih tinggi mengalami depresi. Depresi lebih sering terjadi pada lansia yang tinggal sendiri dibandingkan dengan lansia yang tinggal bersama kerabat/keluarganya (Marta, 2012). Namun dalam penelitian ini mayoritas lansia yang mengalami depresi lansia yang berstatus masih menikah dan tinggal bersama suami atau istrinya. Penelitian Livana (2018) menunjukkan bahwa lansia yang masih memiliki pasangan yang mengalami depresi ringan sebanyak 41,2\%. Hal ini menunjukkan bahwa lansia yang masih mempunyai pasangan juga berisiko mengalami depresi. Lansia yang mempunyai pasangan hidup bisa mengalami depresi. Hal ini dapat terjadi karena adanya perpecahan keluarga dan interaksi antara orang yang depresi 
dengan pasangan hidup (Davinson, dkk, 2005). Namun depresi juga dapat terjadi pada lansia yang tidak memiliki pasangan hidup, hal ini dapat terjadi karena kemarahan yang ditinggalkan oleh pasangan hidup terus menerus berkembang dan menjadi proses menyalahkan diri sendirisehingga terjadi depresi berkelanjutan (Davinson, dkk, 2005). Penelitian yang berkaitan dengan pengaruh pasangan terhadap depresi lansia yang diteliti oleh Hasanah (2014) menunjukkan hasil bahwa terdapat perbedaan tingkat depresi antara lansia yang tidak memiliki pasangan hidup lebih tinggi daripada lansia yang memiliki pasangan hidup (Hasanah, 2014).

Berdasarkan tabel 4.1 dapat diketahui bahwa lansia yang mengalami depresi mayoritas tinggal bersama pasangan suami/istri, sedangkan sebagian kecil lansia yang mengalami depresi adalah lansia yang tinggal sendiri yaitu 3 lansia tinggal sendiri pada kelompok intervensi dan 3 lansia tinggal sendiri pada kelompok kontrol. Tingkat depresi dipengaruhi oleh perhatian dari pengasuhnya, yaitu anggota keluarganya (Sari, 2012). Keluarga sebagai orang terdekat dengan lansia selayaknya memberikan dukungan yang memadai dalam pearawatan lansia di sisa usianya. Penelitian Susilowati menunjukkan bahwa terdapat hubungan yang bermakna antara dukungan keluarga dengan kejadian depresi pada lansia yang tinggal bersama kleuarga di wilayah kerja Puskesmas Kotabumi II Lampung Utara dengan $p$ value 0,020.

Berdasarkan tabel 4.2 dapat diketahui bahwa lansia yang mengalami depresi mayoritas tidak sekolah atau tidak pernah mendapatkan pendidikan. Hal ini sama dengan penelitian Herawati (2019) depresi pada lansia bahwa hubungan antara tingkat pendidikan dengan kejadian depresi diperoleh bahwa ada sebanyak 77 orang $(95,1 \%)$ responden yang mengalami depresi yaitu dengan tingkat pendidikan rendah, sedangkan di antara responden yang mengalami depresi terdapat 4 orang $(4,9 \%)$ responden dengan tingkat pendidikan tinggi. Hasil uji Chi Square didapatkan nilai $\mathrm{p}$ value 0,007 sehingga dapat disimpulkan bahwa terdapat hubungan tingkat pendidikan dengan kejadian depresi (Herawati \& Deharnita, 2019). Sebuah penelitian Winrow (2005) menunjukkan bahwa kurangnya kesempatan untuk bersekolah dan tidak 
adanya fasilitas pendidikan di daerah pedesaan berkontribusi pada kejadian depresi. Pendidikan dapat mempengaruhi seseorang termasuk juga perilakunya akan pola hidup terutama dalam memotivasi untuk sikap, berperan dalam pembangunan kesehatan. Makin tinggi pendidikan seseorang makin mudah menerima informasi, sehingga semakin banyak pula pengetahuan yang dimilki. Sebaliknya, semakin rendah atau kurang pendidikan seseorang akan menghambat perkembangan sikap seseorang terhadap nilai-nilai yang baru diperkenankan (Notoatmodjo, 2005).

Pada tabel 2 dapat diketahui bahwa skor depresi pre test depresi ringan. Mayoritas lansia mengalami depresi ringan dengan rentang skor 5-8. Ada beberapa hal yang dapat mempengaruhi risiko terjadi depresi pada lansia yaitu usia di atas 65 tahun lebih, jenis kelamin perempuan, tinggal sendiri dan status janda/duda (Marta, 2012).

Pada tabel 3 dapat diketahui tingkat depresi post test pada mengalami penurunan skor depresi, yang pada pre test mayoritas depresi ringan, namun setelah dilakukan terapi reminiscence tingkat depresi menjadi normal. Penurunan skor depresi yang bermakna yang dimaksud adalah bahwa kondisi depresi lansia semakin lebih baik dengan ditunjukkan skor depresi menurun setelah mendapatkan terapi reminiscence. Hal ini dikarenakan lansia yang mendapatkan terapi reminiscence mengalami beberapa perubahan yaitu lansia lebih semangat dan merasa bahagia serta hidupnya lebih berguna. Menurut analisa peneliti dan berdasarkan respon peserta didapatkan informasi bahwa terapi reminiscence dapat membuat responden menjadi bahagia, karena mereka mengingat pengalaman masa lalu yang menyenangkan dan bisa saling berbagi pengalaman yang menyenangkan dengan suami atau anak cucu mereka pada saat anak-anak, remaja, dewasa dan masa tua. Hal ini sesuai dengan penelitian Chiang dkk (2009) bahwa terapi reminiscence dapat meningkatkan kemampuan sosial, termasuk perasaan berharga dan menurunkan atau memperbaiki kondisi depresi pada peserta terapi.

Terapi reminiscence merupakan salah satu terapi yang dapat digunakan untuk menurunkan tingkat depresi pada lansia yang mengalami depresi. Terapi reminiscence ini adalah suatu terapi yang 
dapat dipraktekkan di panti jompo atau fasilitas kesehatan lansia (Fujiwara et al., 2012; Tadaka \& Kanagawa, 2007). Beberapa penelitian yang meneliti efek terapi reminiscence pada lansia di panti jompo atau panti wredha adalah penelitian Syarniah (2010), Lestari (2016), Vitaliati (2018) dan Adicondro (2014) yang menunjukkan bahwa terapi reminiscence efektif menurunkan tingkat depresi pada lansia yang tinggal di panti wredha.

Kegiatan terapi reminiscence merupakan kegiatan terapi yang berfokus untuk mengeksplorasi keberhasilan lansia yang pernah dicapai. Terapis memberikan motivasi dan membantu mengingat kejadian-kejadian yang menyenangkan yang pernah dialami lansia pada masa anak-anak, remaja, dewasa, berkeluarga dan pencapaian integritas diri. Pada saat pelaksanaan terapi semua peserta menunjukkan antusias dan tertawa bersama ketika menceritakan masa lalu yang menyenangkan. Perasaan bahagia dan semangat yang ditunjukkan peserta ini kemudian diintegrasikan dengan kemampuan dan keberhasilan lansia pada usia saat ini. Perasaan bahagia ini sangat bermanfaat dalam menurunkan masalah depresi lansia (Hermawati \& Permana, 2020).

Berdasarkan tabel 4 dapat diketahui bahwa nilai $p$ value $0,00<0,05$ sehingga hipotesis diterima yaitu terdapat perbedaan skor depresi lansia pre test dan post test. Hal ini menunjukkan bahwa terdapat pengaruh terapi reminiscence terhadap skor depresi lansia. Hasil penelitian ini sama dengan hasil penelitian Hamzehzadeh (2018) yaitu terapi reminiscence secara signifikan efektif dalam mengurangi depresi dan meningkatkan perasaan optimis pada lansia dalam kelompok eksperimen dengan nilai $p$ value 0,001 (Hamzehzadeh dkk., 2018).

Penelitian Sahu dkk (2019) mengungkapkan bahwa setelah dilakukan RGT (Reminiscence Group Therapy), pada kelompok eksperimen menunjukkan bahwa tingkat depresi menurun (sebelum intervensi $10.08 \pm 1.41$ dan setelah intervensi 6.36 \pm 1.38 ), harga diri meningkat (sebelum intervensi 23.4 \pm 2.69 dan setelah intervensi $29.56 \pm 2.58$ ) dan kesepian berkurang (sebelum intervensi $36.92 \pm 4.57$ dan setelah intervensi 20.96 \pm 5.09 ) secara signifikan. Ada perbedaan yang signifikan secara 
statistik yang ditemukan dalam skor depresi, harga diri dan kesepian di antara kelompok eksperimen dibandingkan dengan kelompok kontrol dengan nilai $\mathrm{p}$ value $<0,0001$. Penelitian ini menyimpulkan bahwa RGT menghasilkan efek positif di antara wanita lansia yang tinggal di panti jompo (Sahu dkk., 2019). Program terapi reminiscence kelompok menunjukkan efek dalam menurunkan tingkat depresi dan meningkatkan makna hidup lansia (Ching-Teng dkk., 2020). Terapi reminiscence memiliki potensi kemanjuran untuk mempertahankan kognisi dan penurunan gejala depresi pada populasi lansia (Gil dkk., 2019). Terapi reminiscence dapat menurunkan kecemasan, depresi dan kesepian pada lansia (Tarugu dkk., 2019). Selain itu terapi reminiscence yang dilaksanakan secara teratur dapat meningkatkan fungsi kognitif, menurunkan gejala depresi, dan meningkatkan kualitas hidup pada lansia (Lök dkk., (2019),Siverová \& Bužgová, (2018), Duru Aşiret \& Kapucu, 2016)).

Rekomendasi dalam penelitian ini ditujukan kepada perawat jiwa komunitas untuk mengintegrasikan terapi reminiscence ke dalam pelayanan asuhan keperawatan pada lansia sebagai salah satu upaya mennagani masalah depresi pada lansia.

\section{KESIMPULAN}

Terapi reminiscence individu yang dilaksanakan secara konsisten dapat membantu mengurangi masalah depresi pada lansia.

Saran penelitian ini ditujukan kepada:

1. Praktisi tenaga kesehatan khususnya perawat dapat mengikuti kegiatan workshop atau pelatihan terapi reminiscence sehingga bisa menjadi terapis dan dapat memberikan kontribusi di masyarakat dalam mengatasi depresi lansia.

2. Masyarakat

Memberikan TOT (Training of Trainer) atau pelatihan sederhana kepada kader kesehatan yang ada di masing-masing dusun atau desa untuk menjadi fasilitator dalam kegiatan terapi reminiscence, sehingga kader kesehatan bisa menjadi fasilitator dalam pelaksanaan terapi reminiscence yang bisa menjadi agenda rutin dalam kegiatan posyandu lansia.

3. Peneliti selanjutnya

Hasil penelitian ini dapat dijadikan 


\begin{abstract}
sebagai evidence based untuk penelitian selanjutnya yang berhubungan dengan kesehatan jiwa pada lansia dengan mengembangkan terapi reminiscence yang dilakukan secara individu maupun kelompok serta dapat melakukan kombinasi dengan terapi spesialis jiwa yang lainnya seperti terapi CBT (Cognitive Behaviour Therapy), Terapi supportif dan lainnya, selain itu peneliti selanjutnya bisa mengembangkan instrumen untuk mengevaluasi atau menggali persepsi dan pengalaman partisipan setelah mengikuti terapi reminiscence.
\end{abstract}

\section{UCAPAN TERIMA KASIH}

Ucapan terima kasih diberikan kepada LPPM STIKES Duta Gama Klaten yang sudah memberikan dana penelitian ini.

\section{REFERENSI}

Adicondro, N. (2014). Pengaruh Terapi Kelompok Reminiscence Untuk Menurunkan Tingkat Depresi Pada Lanjut Usia Di Panti Sosial Tresna Werdha Unit Budi Luhur
Kasongan, Bantul, Daerah Istimewa Yogyakarta, 007.

Akhoondzadeh G, Jalalmanesh S, Hojjati $\mathrm{H}$. Effect of reminiscence on cognitive status and memory of the elderly people. Iran J Psychiatry Behav Sci. 2014;8(3):75-80.

Arwani, dkk. (2019). The Role of Physical Activity in Determining the Level of Older People's Depression. Indian Journal of Public Health Research \& Development . Mar 2019, Vol. 10 Issue 3, p599-603. 5p.

Bappenas, (2015). Laporan Pencapaian Tujuan Pembangunan Milenium di Indonesia 2014. Jakarta.

Chen, T., Li, H., \& Li, J. (2012). The effects of reminiscence therapy on depressive symptoms of Chinese elderly: study protocol of a randomized controlled trial. $B M C$ Psychiatry, 12, 189.

Chiang, K. J. (2009). The Effect of Reminiscence Therapy On Psychological Well-Being, Depression, and Loneliness Among The Institutionalized Aged. International Journal of Geriatric Psychiatry.

Ching-Teng, Y., Ya-Ping, Y., Chia-Ju, L., \& Hsiu-Yueh, L. (2020). Effect of group reminiscence therapy on depression and perceived meaning of life of veterans diagnosed with dementia at veteran homes. Social Work in Health Care, 1-16. https://doi.org/10.1080/00981389. 2019.1710320 
Chueh, K. H., \& Chang, T. Y. (2014). Effectiveness of group reminiscence therapy for depressive symptoms in male veterans: 6-month follow-up. International Journal of Geriatric Psychiatry, 29(4), 377-383.

Davinson, G.C.,Neale, J.M., dan Kring, A.M. (2006). Psikologi abnormal. Jakarta: PTRaja Grafindo Persada.

Duru Aşiret, G., \& Kapucu, S. (2016). The Effect of Reminiscence Therapy on Cognition, Depression, and Activities of Daily Living for Patients With Alzheimer Disease. Journal of Geriatric Psychiatry and Neurology, 29(1), 31-37. https://doi.org/10.1177/08919887 15598233

Fujiwara, E., Otsuka, K., Sakai, A. et al. (2012). Usefulness of reminiscence therapy for community mental health.Psychiatry and Clinical Neurosciences, 66, 74-79.

Gil, I., Costa, P., Cardoso, D., Parola, V., Bobrowicz-Campos, E., de Almeida, M. de L., \& Apóstolo, J. (2018). The effectiveness of reminiscence in cognition, depressive symptoms, and quality of life in elderly people in the community: A systematic review. Revista de Enfermagem Referência, IV Série(19), 147158.

https://doi.org/10.12707/RIV1803 2

Gil, I., Costa, P., Parola, V., Cardoso, D., Almeida, M., \& Apóstolo, J. (2019). Efficacy of reminiscence in cognition, depressive symptoms and quality of life in institutionalized elderly: A systematic review. Revista Da Escola de Enfermagem Da USP, 53, e03458. https://doi.org/10.1590/s1980220x2018007403458

Hamzehzadeh, M., Golzari, M., Rafiemanesh, H., Meshki, V., Abdolalizadeh, M., Hoseini, L., \& Foroughan, M. (2018). Investigating the effectiveness of reminiscence therapy on of elderlies depression and optimism: An experiment study. Prensa Medica Argentina, 104. https://doi.org/10.41720032/745X .1000318

Harini, I.G.A, Setianingsih, P., \& Widjanegara, I. G. (2018). PENGARUH REMINISCENCE THERAPY TERHADAP FUNGSI KOGNITIF PADA LANJUT USIA. Jurnal Gema Keperawatan. 10.

Hermawati, E., \& Permana, I. (2020). MANFAAT TERAPI REMINISCENCE DALAM MENGATASI DEPRESI PADA LANSIA. Jurnal Ilmu Keperawatan Jiwa Persatuan Perawat Nasional Indonesia Jawa Tengah. 3 (1) Hal 41 - 46. e-ISSN 26212978

Hidayati, L. N., Mustikasari, M., \& Eka Putri, Y. S. (2015). Individual Reminiscence Therapy can Decrease Depression Level on Elderly at Social Homes. Jurnal NERS, $10(2), \quad 222$. https://doi.org/10.20473/jn.V10I2 2015.222-232 
Huang, H.-C., Chen, Y.-T., Chen, P.-Y., Huey-Lan Hu, S., Liu, F., Kuo, Y.L., \& Chiu, H.-Y. (2015). Reminiscence Therapy Improves Cognitive Functions and Reduces Depressive Symptoms in Elderly People With Dementia: A MetaAnalysis of Randomized Controlled Trials. Journal of the American Medical Directors Association, 16(12), 1087-1094. https://doi.org/10.1016/j.jamda.20 15.07.010

Jones, E. D. (2003). Reminiscence therapy for older women with depression: Effects of nursing intervention classification in assisted-living long-term care. Journal Gerontology Nursing, 29(7), 26-33. doi:10.3928/00989134-20030701-07

Kaplan HI, Sadock BJ, and G. J. (2010). Sinopsis Psikiatri: Ilmu Pengetahuan Perilaku Psikiatri Klinis. Jilid Satu. Editor: Dr. I. Made Wiguna S. Jakarta: Bina Rupa Aksara.hlm.113-129, 149183.

Keliat, B. A., dkk. (2006). Proses

Keperawatan Jiwa Edisi II. Jakarta: EGC.

Lestari, Feny Mega \& Sumintardja, Elmira. 2016. Kajian Reminiscence Group Theraphy Pada Depresi Lansia Wanita Yang Tinggal Di Panti Werdha. Jurnal Ilmiah Psikologi MANASA 2016, Vol. 5, No. 1, 42-56

Livana, dkk. 2018. Gambaran Tingkat Depresi Lansia. Nurscope. Jurnal Keperawatan Pemikiran Ilmiah. 4(4).80-93
Lök, N., Bademli, K., \& Selçuk-Tosun, A. (2019). The effect of reminiscence therapy on cognitive functions, depression, and quality of life in Alzheimer patients: Randomized controlled trial. International Journal of Geriatric Psychiatry, 34(1), 47-53. https://doi.org/10.1002/gps.4980

Marta, O. F. (2012). Determinan Tingkat Depresi Pada Lansia Di Panti Sosial Tresna Werdha Budi Mulia 4 Jakarta Selatan. Universitas Indonesia.

Monteleone, P. (2011). Endocrine Disturbances and Psychiatric Disorders.CurrentOpinion in Psychiatry. 2001;14(6):605-10.

Montorio, A. \& Izal, M. (1996). The geriatric depression scale: a review of its development and utility. International Psychogeriatrics, Vol.8, No.1, h. 103-112

Mufatikah, L. (2014). Studi Komparasi Tingkat Depresi pada Lansia yang Melakukan dan Tidak Melakukan Sanam Lansia di Pstw Yogyakarta Unit Budi Luhur dan Posyandu Lansia Bougenvile Sumbermulyo Bantul. Skripsi (Diterbitkan). Yogyakarta: Sekolah Tinggi ILmu Kesehatan 'Aisyiyah Yogyakarta.

Nutt, D.J. (2008). Relationship of Neurotransmitters to the Symptoms of Major Depressive Disorder.Journal of Clinical Psychiatry. 2008;69 Suppl E1:4-7. PMID 18494537

Pinquart, M., \& Forstmeier, S. (2012). Effects of reminiscence interventions on psychosocial 
outcomes: A meta-analysis. Aging \& Mental Health, 16(5), 541-558.

Pramesona, B. A., \& Taneepanichskul, S. (2018). Prevalence and risk factors of depression among Indonesian elderly: A nursing home-based cross-sectional study. Neurology, Psychiatry and Brain Research, 30, 22-27. https://doi.org/10.1016/j.npbr.201 8.04 .004

Sahu, I., Mohanty, S., \& Pahantasingh, S. (2019). Effect of reminiscence group therapy on depression, selfesteem and loneliness among elderly women residing in old age home. International Journal of Research in Medical Sciences, 7(10), 3685. https://doi.org/10.18203/23206012.ijrms20194293

Sari, Nelda Nilam. (2012). Pengaruh Dukungan Sosial Terhadap Depresi pada Lansia. Uns. Medan.

Sarokhani, D., Parvareh, M., Hasanpour Dehkordi, A., Sayehmiri, K., \& Moghimbeigi, A. (2018). Prevalence of Depression among Iranian Elderly: Systematic Review and MetaAnalysis. Iranian journal of psychiatry, 13(1), 55-64.

Siverová, J., \& Bužgová, R. (2018). The effect of reminiscence therapy on quality of life, attitudes to ageing, and depressive symptoms in institutionalized elderly adults with cognitive impairment: A quasi-experimental study. International Journal of Mental Health Nursing, 27(5), 1430-
1439.

https://doi.org/10.1111/inm.12442

Susilowati, Fepi \& Yenie, Helmi. 2015. Hubungan Dukungan Keluarga Terhadap Kejadian Depresi Pada Lansia Yang Tinggal Bersama Keluarga Di Wilayah Kerja Puskesmas Kota Bumi II Lampung Utara. Jurnal Kesehatan Metro Sai Wawai Volume VIII No 2. ISSN 19779-469X.

Syarniah. (2010). Pengaruh Terapi Kelompok Reminiscence Terhadap Depresi Pada Lansia Di Panti Sosial Tresna Werdha Budhi Sejahtera Provinsi Kalimantan Selatan. Tesis. Universits Indonesia.

Tadaka, E. \& Kanagawa, K. (2007). Effects of reminiscence group in elderly people with Alzheimer disease and vascular dementia in a community setting. Geriatrics \&Gerontology International, 7, 167-173.

Tarugu, J., Pavithra, R., Vinothchandar, S., Basu, A., Chaudhuri, S., \& John, K. R. (2019). Effectiveness of structured group reminiscence therapy in decreasing the feelings of loneliness, depressive symptoms and anxiety among inmates of a residential home for the elderly in Chittoor district. International Journal Of Community Medicine And Public Health, 6(2), 847. https://doi.org/10.18203/23946040.ijcmph20190218

United Nations, Department of Economic and Social Affairs, Population Division (2015). 
United Nations: World Population Ageing; 2015 (ST/ESA/SER. A/390).

https://www.un.org/en/developme nt/desa/population/publication/ pdf/ageing/WPA2015_Report.pdf.

Vitaliati, T. (2018). Pengaruh Penerapan Reminiscence Therapy Terhadap Tingkat Depresi Pada Lansia. (1), 6.

Woods, B., O’Philbin, L., Farrell, E. M., Spector, A. E., \& Orrell, M. (2018). Reminiscence therapy for dementia. Cochrane Database of Systematic Reviews. https://doi.org/10.1002/14651858. CD001120.pub3

World Health Organization. (2011). Global health and aging. Retrieved from

http://www.who.int/ageing/public ations/global health.pdf diakses pada tanggal 21 Juni 2019

World Health Organization. (2015). Mental health and older adults.https://www.bappenas.go.id /files/5413/9148/4109/Proyeksi P enduduk_Indonesia_2010-

2035.pdf diakses tanggal $21 \mathrm{Juni}$ 2019.

Wu, D., Chen, T., Yang, H., Gong, Q., \& $\mathrm{Hu}, \mathrm{X}$. (2018). Verbal responses, depressive symptoms, reminiscence functions and cognitive emotion regulation in older women receiving individual reminiscence therapy. Journal of Clinical Nursing, 27(13-14), 2609-2619. https://doi.org/10.1111/jocn.1415 6
Wu, L.. (2011). Group integrative reminiscence therapy on selfesteem, life satisfaction and depressive symptoms in institutionalised older veterans. Journal of Clinical Nursing Vol 20 (15) 2195-2203.

Yang, Y.-P., Lee, F.-P., Chao, H.-C., Hsu, F.-Y., \& Wang, J.-J. (2016). Comparing the Effects of Cognitive Stimulation, Reminiscence, and AromaMassage on Agitation and Depressive Mood in People With Dementia. Journal of the American Medical Directors Association, 17(8), 719-724. https://doi.org/10.1016/j.jamda.20 16.03.021

Yen, H.-Y., \& Lin, L.-J. (2018). A Systematic Review of Reminiscence Therapy for Older Adults in Taiwan: Journal of Nursing Research, 26(2), 138150.

https://doi.org/10.1097/jnr.000000 0000000233 